\title{
Using HiEduQual to Assess Student Satisfaction in Selected Higher Educational Institutions in North India
}

\author{
Bushra S. P. Singh (Corresponding author) \\ University Business School, Arts Block III; \\ Panjab University; Sector 14 \\ Chandigarh - 160014, India
}

Tel: 91-95306-65864Ｅ-mail: bushra.spsingh@gmail.com

Received: October 27, 2015 Accepted: November 13, 2015 Published: March 5, 2016

doi:10.5296/ire.v4i1.8439

URL: http://dx.doi.org/10.5296/ire.v4i1.8439

\begin{abstract}
Purpose - The purpose of this study is to assess the service quality gaps in 4 universities and 6 colleges in Chandigarh, Punjab and Haryana using the HiEduQual questionnaire.

Methodology - Data collected from 256 first year students and 248 final year students was analysed using MS Excel and average expectations and perceptions score were obtained for all six dimensions namely, teaching, administrative services, academic facilities, campus infrastructure, support services and internationalization.
\end{abstract}

Findings -Quantitative analysis revealed negative gap scores in all six dimensions.

Practical implications - Management in higher educational institutions must upgrade the ICT infrastructure in campuses. There must be use of information systems, online fees payment, interactive whiteboards for classroom teaching. Faculty exchange programmes and Industry Institute Interactions must be encouraged. Students must be offered e-library facilities, counselling services, placement services, sports and recreational facilities.

Keywords: Service Quality, HiEduQual, Universities, Colleges, Higher Educational Institutions

\section{Introduction}

India has experienced rapid growth in Education in response to rising demand. The higher education sector has grown by leaps and bounds since Independence in 1947. In India, Higher Education is the shared responsibility of the centre and state governments. There are 677 
universities, 45 Central Universities, 318 State Universities, 185 State Private Universities, 129 Deemed to be Universities, 51 Institutions of National importance (Indian Institute of Technology - 16, National Institute of Technology - 30 and Indian Institute of Science, Education and Research - 5) and four Institutions (established under various State legislations) in India as of 2014. There are 37,204 colleges as of 2013 (Ministry of Human Resource Development, Government of India).

Chandigarh is a union territory that serves as the capital of both Punjab and Haryana states of India. It was established on 1 November, 1966 and is controlled by the Union Government of India. There are nine colleges under the Department of Higher Education, Chandigarh of which five are degree colleges. Three colleges impart education in the areas of Home science, Yoga, Health and Education. Two colleges namely, the State Council of Educational Research \& Training and the Regional Institute of English provide training to in-service teachers. Nearly eighteen thousand students are enrolled in degree colleges in Chandigarh (Department of Higher Education, Chandigarh Administration).

The state of Punjab has a higher enrolment rate per college than the all India level. Also, the participation of women in education in Punjab is the highest as compared to other Indian states. Nearly $90 \%$ of the students in Punjab are enrolled in undergraduate courses, $7.79 \%$ are enrolled in postgraduate courses and $0.16 \%$ are enrolled in research programmes. There is a Central University situated in the district of Bathinda and 10 state universities. There are 55 government colleges, 136 government aided colleges and 188 private colleges in Punjab. In 2007, Indian Institute of Science, Education and Research was set up in Mohali. (Directorate of Public Instructions (Colleges), Punjab). Recently, Indian Institute of Management was established in Amritsar.

The state of Haryana was carved out of the southern districts of Punjab in 1966. Haryana has a central university in the district of Mahendergarh and 10 state universities. There are 622 technical institutions with annual intake of nearly 143000, 2 minority institutions, 3 deemed universities, 8 private universities, 4 Government of India Institutions and 4 State of Art Institutions as of 2013 (Department of Technical Education, Haryana).

Nowadays, Institutes are facing stiff competition and are racing against each other to make it to the top of the world rankings. Students are willing to pay any price for the desired stream and thus private competitors are becoming a more popular destination as compared to their public counterparts. There are very few world class institutions in India and limited research is taking place in Indian Institutions due to lack of investment in libraries, laboratories, classrooms, information technology, biotechnology, nanotechnology etc. If India is to evolve into a superpower, then there has to be an upsurge in student enrolment as well as quality improvement in higher education. For this, students need to be perceived as stakeholders in Quality Assurance (Leisyte et al., 2013). Thus, measurement of the expectations and perceptions of students regarding service quality of higher educational institutions is an effective tool in bridging gaps. This paper studies the service quality gaps in ten higher educational institutions in Chandigarh, Punjab and Haryana using the HiEduQual model designed for the Indian Higher Education Sector. 


\subsection{Statement of the Problem}

The present study focuses on the gaps in the student expectations and student perceptions regarding the service quality of ten higher educational institutions in Chandigarh, Punjab and Haryana.

\subsection{Significance of the Research}

This is the first paper to shed light on the service quality of selected higher educational institutions in Chandigarh, Punjab and Haryana as measured by the HiEduQual tool. This study contributes toward the knowledge on service quality of educational institutions. This study presents a realistic assessment of how successful the government and private higher educational institutions have been in meeting their objectives. The present study also contributes to the knowledge by adding literature on north Indian universities/colleges. This issue is essential to be studied since it can contribute to a more comprehensive understanding of educational service quality. Since India is emerging as a global higher education hub, the leadership, faculty and staff at higher educational institutions will benefit by knowing the gaps in the student expectations and perceptions regarding service quality and make quality improvements.

\subsection{Research Questions}

This paper answers the question of how satisfied students are with the services offered by the higher educational institutions. The research question is posed as follows-

- What is the gap between students' expectations of the quality of services provided by the higher educational institutions in Chandigarh, Punjab and Haryana and their perceptions of the quality of services actually delivered?

\subsection{Conceptual and Operational Definition}

Service Quality: is the discrepancy between a customer's expectation of a service and the customer's perception of the service offering (Parasuraman et al., 1985; Seth, Deshmukh, \& Verat, 2005).

Operational definition: Gaps are analysed in the service quality of six dimensions namely, teaching, administrative services, academic facilities, campus infrastructure, support services and internationalization using the HiEduQual questionnaire (Annamdevula \& Bellamkonda, 2014).

\section{Literature Review}

\subsection{Service Quality of Higher Educational Institutions in Developing Economies}

Service Quality essentially refers to an assessment of how well a delivered service conforms to the client's expectations. The SERVQUAL model was proposed by Parasuraman et al. in 1985. This model measured the discrepancy between a customer's expectations and perceptions regarding the service offered. As a result, gaps were analysed in the service quality of five dimensions namely, tangibility, reliability, responsiveness, assurance and 
empathy. Later on, Cronin and Taylor (1992) proposed the SERVPERF model to give it a more predictive and convergent value. Also, it captured only the perceptions of the customers. The SERVQUAL tool has been modified by various researchers for the education sector. Some of these studies have been highlighted below.

Sabina Đonlagić and Samira Fazlić (2015) adapted the SERVQUAL scale for the Higher Educational Institutes in order to determine the service quality of Faculty of Economics, Bosnia and Herzegovina. Research was conducted among 73 students enrolled in the Faculty of Economics and negative gap scores were obtained in all dimensions. The largest gap score was obtained for empathy followed by responsiveness, tangibles, assurance and reliability.

Amran Rasli, Ahmadreza Shekarchizadeh and Muhammad Jawad Iqbal (2012) conducted a study to analyse gaps in the expectations and perceptions of service quality in higher education sector among Iranian postgraduate students enrolled in Malaysian Universities. Modified SERVQUAL was administered to 163 Iranian students enrolled in the top five public universities located in Malaysia based on stratified sampling. Largest negative gap score was obtained for empathy dimension followed by reliability, responsiveness, assurance and tangibles.

Otávio José De Oliveira and Euriane Cristina Ferreira (2009) proposed an adapted version of the SERVQUAL for the higher education sector. The expectations regarding the service quality was assessed among 38 entering students and the perceptions were measured among 28 graduating students of the Production Engineering course in Sao Paulo State University (UNESP), Brazil using the modified SERVQUAL scale. The results revealed that all service quality dimensions namely, promptness, empathy, reliability, security and tangibility had negative gap scores. The highest gap was observed for promptness dimension.

Khanchitpol Yousapronpaiboon (2013) conducted a study among 350 undergraduate students in Thailand and observed that there was a gap between the students' service perceptions and expectations. Thus, the undergraduate students were not satisfied with the higher education system in Thailand. Further, there is a need for more facilities and equipment to improve the quality of service provided by Institutions in Thailand.

Shpëtim Çerri (2012) modified the SERVQUAL instrument to assess the service quality of public higher educational institutions in Albania. Data was collected from 261 students enrolled in bachelor and master programs in five public universities of Albania. Negative gap scores were observed for each dimension, the highest being for reliability, followed by assurance, empathy, tangibles and responsiveness.

Dr. Rita Chopra, Mamta Chawla and Dr. Tejinder Sharma (2014) studied the service quality of 10 institutions in Haryana, India using the modified SERVQUAL. 500 students participated in the study and it was observed that the students are dissatisfied as there were negative gaps between expectations and perceptions of students regarding the service quality dimensions.

Mohammadkarim Bahadori, Jamil Sadeghifar, Mostafa Nejati, Pejman Hamouzadeh and Mostafa Hakimzadeh (2011) using the standard SERVQUAL instrument collected data from 
135 paramedical students enrolled in School of Allied Medical Sciences, Tehran University of Medical Sciences located in Tehran, Iran. Results showed negative service quality gaps in all the five dimensions.

Taraneh Enayati, Yasaman Modanloo, Reza Behnamfar and Abbas Rezaei (2012) administered the SERVQUAL questionnaire to 373 students of the Islamic Azad University of Mazandaran, Iran. The results showed significant differences between the expectations and perceptions of students regarding the five service quality dimensions.

Mukondeleli G. Kanakana (2014) administered the SERVQUAL questionnaire to 200 industrial engineering students enrolled in the Department of Industrial Engineering, Tshwane University of Technology, South Africa. The results revealed that there is a gap between the expectations and perceptions of the service quality mainly in the tangibles and responsiveness dimensions.

R. Dirkse van Schalkwyk and R. J. Steenkamp (2014) conducted a study to determine the service quality of South African Private Higher Education Institutes (PHEI) using the SERVQUAL. The research objective was to promote service quality leadership, measurement and management at the institutes using SERVQUAL. Data was collected from a total of 984 students enrolled in the five campuses of the PHEIs. Results revealed that the service quality gaps in the PHEIs were small as compared to those in the public universities. Thus, it was concluded that service quality as perceived by the students is at a satisfactory level in the PHEIs. However, there exist negative gaps that need to be bridged.

Sangeeta Sahney, D. K. Banwet and S. Karunes (2015) conducted a study to determine the service quality of Indian engineering and management institutes. SERVQUAL questionnaires collected from 219 students were analysed and it was observed that there were negative gaps in service quality dimensions indicating dissatisfaction among students with the services offered by institutes. Further, the authors have classified students as 'customers of the educational system' and concluded that a customer orientation is required to enhance the service quality of Indian educational institutions.

Mtra. Claudia Castillo Cruz, Luis Antonio Delgadillo Gutiérrez and Mtra. Graciela Lara López (2011) conducted a study using the adapted version of the SERVQUAL instrument. 300 students of the Centre of Exact Sciences and Engineering, University of Guadalajara, Mexico were administered the questionnaire and results revealed that there were negative gap scores in all the five service quality dimensions.

As can be seen, students in most of the developing economies are dissatisfied with the services offered by the higher educational institutions. There is a need to revamp the higher education system through up gradation of facilities and technology infrastructure. Nowadays, a market orientation is required to operate institutes effectively. Students and parents are essentially customers and their satisfaction is imperative for the success of any institution.

\subsection{SERVQUAL Model}

The SERVQUAL model (Parasuraman et al., 1985) shown in figure 1 below is used to assess 


\section{Macrothink Institute ${ }^{T M}$}

the reasons for gaps between the customer expectations and perceptions regarding the service quality dimensions.

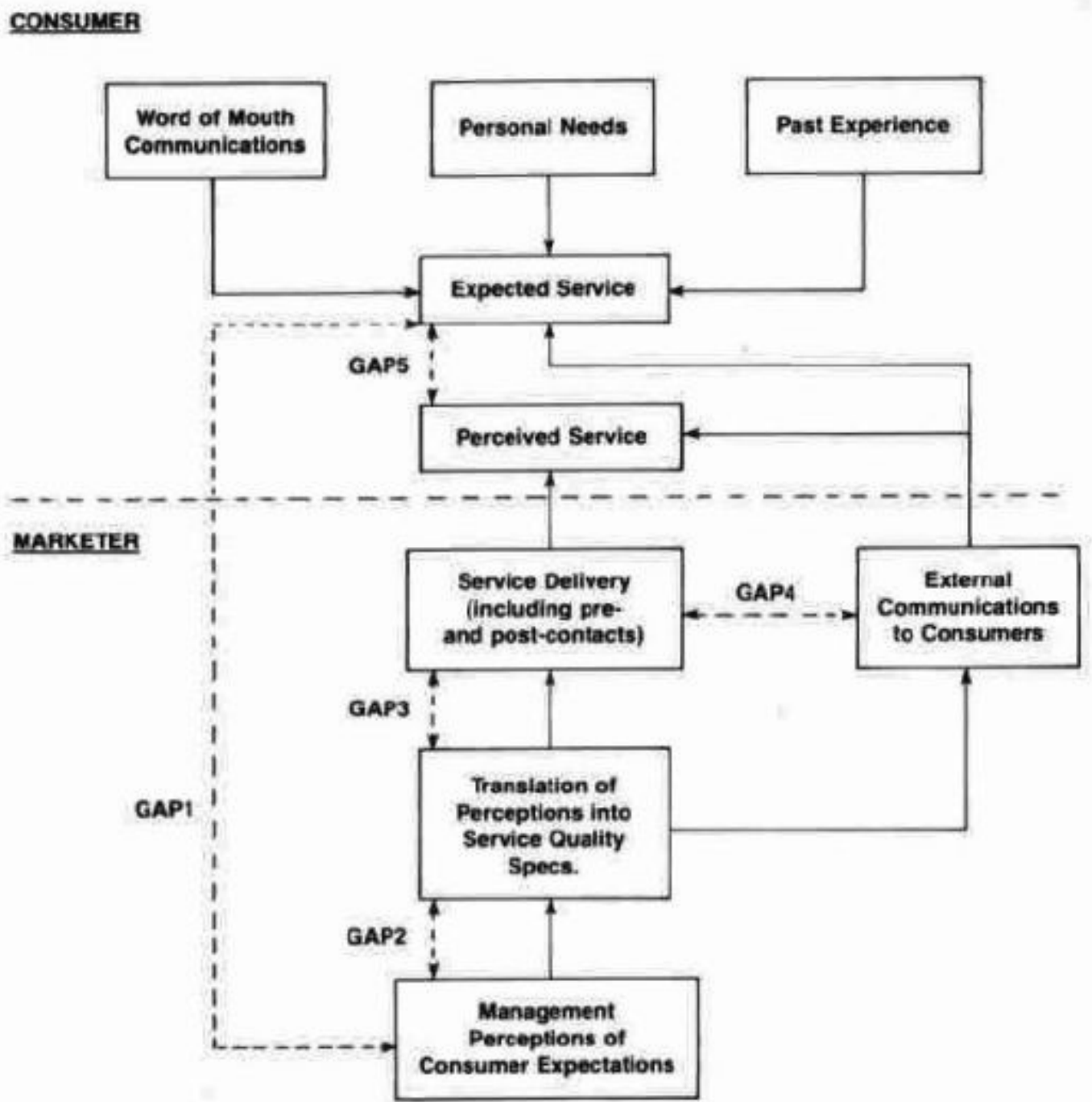

Figure 1. Service Quality Model (Parasuraman, Zeithaml, \& Berry, 1985)

There are four gaps between the customer and the company as given-

Gap 1 - between customer expectations and what the company thinks the customers expect.

- Gap 2 - between customer expectations and service standards.

$>$ Gap 3 - between company's service offering and the specified standard.

$>$ Gap 4 - between the company's communications with customers and service delivery.

$>$ Gap 5 - is the product of the above four gaps. If all the four gaps are closed then the gap 5 closes.

Therefore, Parasuraman et al. (1985) developed a 22-item questionnaire to assess this gap. It 


\section{Macrothink}

comprises five service quality dimensions.

1. Tangibility - the physical facilities, equipment and appearance of personnel

2. Reliability - the ability to perform the promised service dependably and accurately

3. Responsiveness - the willingness to help customers and provide prompt service

4. Assurance - the knowledge and courtesy of employees and their ability to inspire trust and confidence

5. Empathy - caring, individualized attention the firm provides its customers.

\subsection{HiEduQual Model}

Numerous researchers have adapted the SERVQUAL model for the education sector considering the student and parents as customers and teachers as service providers of education. HiEduQual (Annamdevula and Bellamkonda, 2014) is a model designed for the Higher Education Institutions. Based upon the HiEduQual model, a 23-item instrument has been developed comprising six service quality dimensions.

1. Teaching $(\mathrm{T})$ - teaching practices, course content, syllabus

2. Administrative Services (AS) - efficiency, timeliness and attitude of staff, records

3. Academic Facilities (AF) - classroom aids, labs, libraries

4. Campus Infrastructure (CI) - sports and recreational facilities, hostel facilities, safety

5. Support Services (SS) - amenities, extracurricular activities, counselling services

6. Internationalization (I) - international activities, foreign faculty

The HiEduQual model for this study is shown in Figure 2 below. The six dimensions contribute to the Students' Perceived Service Quality (SPSQ).

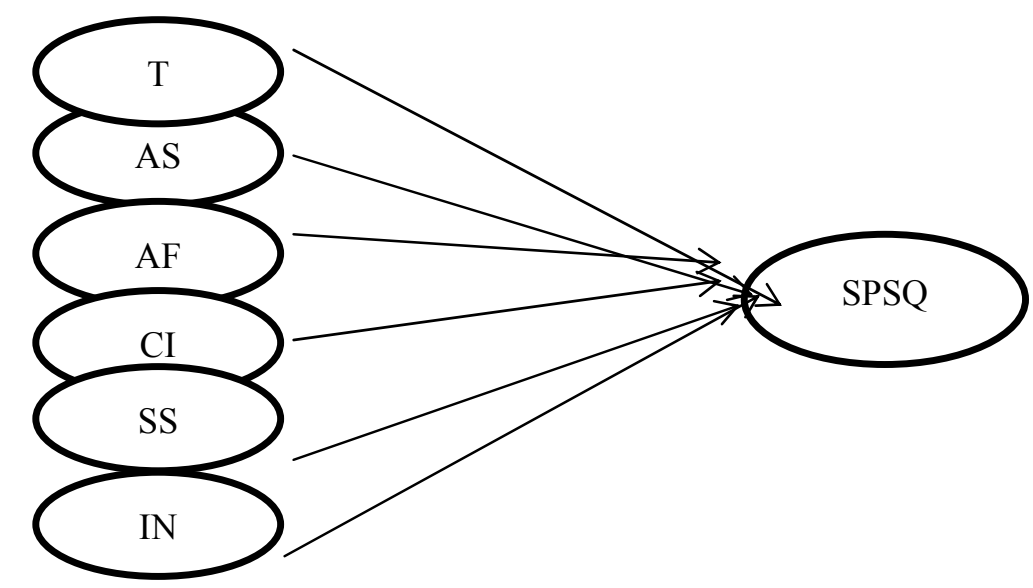

Figure 2. Research Model for this study

\section{Method}

\subsection{Sampling}

A cross-sectional survey design was used in the present study. A total of 10 institutes were selected for data collection in Chandigarh, Punjab and Haryana. 2 universities and 1 college 
were selected in Punjab, 1 university and 3 colleges were selected in Chandigarh and 1 university and 2 colleges were selected in Haryana for the purpose of data collection based on convenience sampling method. Further the respondents for the study were selected based upon snowball sampling method. The first year students were targeted for the assessment of service quality expectations while the final year students enrolled in the same university/college were targeted for the assessment of service quality perceptions. 256 responses from first year students and 248 responses from final year students formed the final sample for data analysis.

\subsection{HiEduQual}

HiEduQual is an adapted version of the SERVQUAL for the Indian higher education sector designed by Subrahmanyam Annamdevula and Raja Shekhar Bellamkonda (2014). It is a 23-item instrument for assessing student perceptions and expectations regarding the service quality of Indian higher education sector. It has six dimensions namely, teaching (7 items), administrative services (5 items), academic facilities (3 items), campus infrastructure (3 items), support services ( 3 items) and internationalization ( 2 items). The expectations vs. perceptions gap model (Parasuraman et al., 1985) was used in the present study. The rating scale is 7-point likert. The maximum score for each item is 7 and the lowest is 1 . Its reliability is greater than 0.90 cronbach alpha. Some examples are "Teachers are responsive and accessible", "Classrooms are equipped with teaching aids".

\subsection{Procedure}

The questionnaire was administered to students enrolled in 4 universities and 6 colleges in Chandigarh, Punjab and Haryana. The duration for questionnaire completion is 6 to 8 minutes. 270 questionnaires were distributed to the first year students of which 260 were returned. 4 questionnaires were rejected as they were partially filled. 256 questionnaires were finally selected for the analysis. 290 questionnaires were distributed to the final year students of which 254 were returned. 6 questionnaires were rejected as they were incomplete and 248 were accepted for the analysis.

\subsection{Data Analysis}

Data analysis was performed on Microsoft Excel Version 7. The HiEduQual score was calculated for the six service quality dimensions namely, teaching, administrative services, academic facilities, campus infrastructure, support services and internationalization by subtracting the perception $(\mathrm{P})$ score from the expectations (E) score (gap score $=\mathrm{P}-\mathrm{E}$ ). Negative gap scores indicate dissatisfaction with services while positive gap scores indicate that expectations have been met. The average HiEduQual P score was also obtained.

\section{Results}

This section presents the results of various analyses in the study. These include the analyses of teaching, administrative services, academic facilities, campus infrastructure, support services and internationalization dimensions. 


\subsection{Sample Characteristics}

Table 1 below depicts the respondents' characteristics. Within the sample, 256 respondents $(50.8 \%)$ were in first year of their study while 248 respondents $(49.2 \%)$ were in the final year of their study. 225 respondents $(44.6 \%)$ were enrolled in public higher educational institutions while 279 respondents $(55.4 \%)$ were enrolled in private higher educational institutions. 281 respondents $(55.7 \%)$ were males and 223 respondents $(44.3 \%)$ were females. 187 respondents (37.1\%) were studying in higher educational institutions located in Chandigarh, 165 respondents (32.7\%) in Punjab and 152 respondents (30.2\%) in Haryana. 248 respondents $(49.2 \%)$ were pursuing undergraduate courses, 228 respondents $(45 \%)$ were pursuing postgraduate courses and 28 respondents $(5.8 \%)$ were pursuing doctoral courses.

Table 1. Respondent's characteristics

\begin{tabular}{|c|c|c|c|}
\hline & Variable & Frequency & Percentage \\
\hline \multirow{2}{*}{ Year } & First Year & 256 & $50.8 \%$ \\
\hline & Final Year & 248 & $49.2 \%$ \\
\hline \multirow{2}{*}{ Ownership of Institute } & Public & 225 & $44.6 \%$ \\
\hline & Private & 279 & $55.4 \%$ \\
\hline \multirow{2}{*}{ Gender } & Male & 281 & $55.7 \%$ \\
\hline & Female & 223 & $44.3 \%$ \\
\hline \multirow{3}{*}{ State } & Chandigarh & 187 & $37.1 \%$ \\
\hline & Punjab & 165 & $32.7 \%$ \\
\hline & Haryana & 152 & $30.2 \%$ \\
\hline \multirow{3}{*}{ Course } & Undergraduate & 248 & $49.3 \%$ \\
\hline & Postgraduate & 228 & $45.2 \%$ \\
\hline & Doctoral & 28 & $5.5 \%$ \\
\hline
\end{tabular}

\subsection{Analysis of Results}

Table 2 below shows the tabulation of data. The average expectations and perceptions scores are generated for each dimension and the average gap score is obtained for all dimensions. 
Table 2. Tabulation of Data

\begin{tabular}{|c|c|c|c|c|c|c|c|c|c|c|c|c|c|c|c|c|c|c|}
\hline & \multicolumn{8}{|c|}{ Expectations } & \multicolumn{8}{|c|}{ Perceptions } & \multirow{3}{*}{$\begin{array}{c}\text { Gap } \\
\text { (P-E) }\end{array}$} \\
\hline & & \multicolumn{7}{|c|}{ Frequency of Responses } & \multirow{2}{*}{ Avg } & \multicolumn{7}{|c|}{ Frequency of Responses } & \multirow{2}{*}{ Avg } & \\
\hline & & 1 & 2 & 3 & 4 & 5 & 6 & 7 & & 1 & 2 & 3 & 4 & 5 & 6 & 7 & & \\
\hline \multirow{8}{*}{$F$} & 1 & 10 & 15 & 23 & 12 & 32 & 65 & 99 & 5.47 & 36 & 46 & 59 & 48 & 17 & 24 & 18 & 3.44 & -2.03 \\
\hline & 2 & 5 & 10 & 17 & 13 & 22 & 87 & 102 & 5.76 & 46 & 53 & 49 & 40 & 25 & 22 & 13 & 3.25 & -2.50 \\
\hline & 3 & 4 & 11 & 12 & 26 & 43 & 65 & 95 & 5.61 & 32 & 68 & 47 & 31 & 36 & 18 & 16 & 3.36 & -2.25 \\
\hline & 4 & 25 & 34 & 20 & 53 & 43 & 24 & 57 & 4.39 & 32 & 43 & 35 & 54 & 21 & 36 & 27 & 3.83 & -0.56 \\
\hline & 5 & 15 & 21 & 22 & 31 & 32 & 47 & 88 & 5.10 & 36 & 33 & 45 & 46 & 23 & 43 & 22 & 3.82 & -1.28 \\
\hline & 6 & 18 & 16 & 18 & 28 & 23 & 55 & 98 & 5.26 & 42 & 54 & 51 & 29 & 21 & 37 & 14 & 3.40 & -1.86 \\
\hline & 7 & 28 & 13 & 18 & 21 & 34 & 47 & 95 & 5.11 & 55 & 47 & 45 & 43 & 15 & 17 & 26 & 3.29 & -1.83 \\
\hline & \multicolumn{18}{|c|}{ Average Teaching Gap score $=\mathbf{- 1 . 7 6}$} \\
\hline \multirow{6}{*}{ 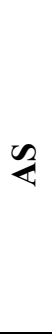 } & 8 & 13 & 22 & 12 & 10 & 31 & 85 & 83 & 5.39 & 33 & 35 & 65 & 50 & 23 & 14 & 28 & 3.60 & -1.79 \\
\hline & 9 & 6 & 15 & 17 & 9 & 36 & 83 & 90 & 5.59 & 45 & 41 & 62 & 37 & 29 & 12 & 22 & 3.35 & -2.24 \\
\hline & 10 & 16 & 14 & 33 & 25 & 11 & 65 & 92 & 5.20 & 34 & 52 & 49 & 38 & 32 & 27 & 16 & 3.51 & -1.69 \\
\hline & 11 & 7 & 12 & 10 & 9 & 34 & 83 & 101 & 5.75 & 38 & 67 & 43 & 31 & 32 & 23 & 14 & 3.31 & -2.44 \\
\hline & 12 & 10 & 32 & 38 & 12 & 32 & 45 & 87 & 4.98 & 53 & 35 & 53 & 52 & 35 & 8 & 12 & 3.21 & -1.77 \\
\hline & \multicolumn{18}{|c|}{ Average Administrative Services Gap score $=\mathbf{- 1 . 9 9}$} \\
\hline \multirow{4}{*}{$\frac{5}{4}$} & 13 & 21 & 15 & 11 & 45 & 12 & 67 & 85 & 5.16 & 20 & 46 & 42 & 58 & 32 & 19 & 31 & 3.88 & -1.29 \\
\hline & 14 & 26 & 12 & 18 & 33 & 32 & 58 & 77 & 5.01 & 31 & 46 & 45 & 52 & 32 & 6 & 36 & 3.69 & -1.33 \\
\hline & 15 & 21 & 32 & 21 & 15 & 25 & 54 & 88 & 4.97 & 22 & 37 & 60 & 33 & 23 & 41 & 32 & 4.00 & -0.97 \\
\hline & \multicolumn{18}{|c|}{ Average Academic Facilities Gap score $=\mathbf{- 1 . 2 0}$} \\
\hline \multirow{4}{*}{$\bar{\tau}$} & 16 & 15 & 32 & 22 & 17 & 12 & 75 & 83 & 5.09 & 12 & 38 & 47 & 65 & 31 & 23 & 32 & 4.06 & -1.04 \\
\hline & 17 & 12 & 13 & 7 & 13 & 33 & 76 & 102 & 5.65 & 25 & 51 & 59 & 45 & 34 & 13 & 21 & 3.54 & -2.10 \\
\hline & 18 & 12 & 7 & 15 & 26 & 32 & 65 & 99 & 5.54 & 44 & 48 & 65 & 33 & 32 & 12 & 14 & 3.21 & -2.33 \\
\hline & \multicolumn{18}{|c|}{ Average Campus Infrastructure Gap score $=\mathbf{- 1 . 8 2}$} \\
\hline \multirow{4}{*}{ \& } & 19 & 11 & 32 & 22 & 13 & 15 & 62 & 101 & 5.26 & 42 & 48 & 35 & 65 & 38 & 9 & 11 & 3.32 & -1.94 \\
\hline & 20 & 9 & 16 & 12 & 15 & 34 & 59 & 111 & 5.62 & 36 & 22 & 67 & 54 & 41 & 7 & 21 & 3.59 & -2.02 \\
\hline & 21 & 15 & 8 & 23 & 17 & 53 & 74 & 66 & 5.23 & 33 & 16 & 58 & 65 & 32 & 21 & 23 & 3.81 & -1.42 \\
\hline & \multicolumn{18}{|c|}{ Average Support Services Gap score $=-1.79$} \\
\hline \multirow[b]{2}{*}{$\mathbf{Z}$} & 22 & 35 & 37 & 32 & 9 & 33 & 48 & 62 & 4.41 & 141 & 21 & 35 & 28 & 6 & 10 & 7 & 2.17 & -2.23 \\
\hline & 23 & 42 & 26 & 18 & 23 & 26 & 39 & 82 & 4.60 & 156 & 30 & 13 & 14 & 18 & 8 & 9 & 2.06 & -2.54 \\
\hline
\end{tabular}

\subsubsection{Analysis of Teaching Scores}

The Teaching dimension of the HiEduQual tool comprises the first seven questions which assess respondents' perceptions of the teaching practices, course curriculum, course content and syllabus of the higher educational institutions under study. When looking at each of the seven factors making up the teaching dimension, the expectations of the students exceed their perceptions in all areas. 
The average gap score (P-E) for the teaching dimension of service quality is -1.76 . In all cases, the survey results show that the perception of the students of the ten higher educational institutions under study regarding the service quality do not meet their expectations.

A summary of the survey results for the teaching dimension of student customer service quality are summarized in Table 3 below.

Table 3. Teaching Dimension - HiEduQual Results

\begin{tabular}{lcccc}
\hline \multicolumn{1}{c}{$\begin{array}{c}\text { T FACTOR } \\
\text { DIMENSIONS }\end{array}$} & $\begin{array}{c}\text { EXPECTATION } \\
\text { (E) }\end{array}$ & $\begin{array}{c}\text { PERCEPTION } \\
\text { (P) }\end{array}$ & $\begin{array}{c}\text { GAP } \\
\text { SCORE } \\
\text { (P-E) }\end{array}$ & $\begin{array}{c}\text { AVERAGE } \\
\text { SERVQUAL P } \\
\text { SCORE FOR T }\end{array}$ \\
\hline $\begin{array}{l}\text { 1.Teachers are responsive } \\
\text { and accessible }\end{array}$ & 5.47 & 3.44 & -2.03 & \\
$\begin{array}{l}\text { 2.Course content develops } \\
\text { students' knowledge }\end{array}$ & 5.76 & 3.25 & -2.50 & \\
$\begin{array}{l}\text { 3.Teachers follow good } \\
\text { teaching practices }\end{array}$ & 5.61 & 3.36 & -2.25 & \\
$\begin{array}{l}\text { 4.Teachers follow } \\
\text { curriculum strictly }\end{array}$ & 4.39 & 3.83 & -0.56 & \\
$\begin{array}{l}\text { 5.Teachers continuously } \\
\text { evaluate } \\
\text { performance students' }\end{array}$ & 5.10 & 3.82 & -1.28 & \\
$\begin{array}{l}\text { 6.Department has sufficient } \\
\text { academic staff }\end{array}$ & 5.26 & 3.40 & -1.86 & \\
$\begin{array}{l}\text { 7.Collects feedback to } \\
\text { provide better services }\end{array}$ & 5.11 & 3.29 & -1.83 & \\
\hline \multicolumn{1}{c}{ Average Teaching Gap Score } & & -1.76 & \\
\hline
\end{tabular}

\subsubsection{Analysis of Administrative Services Scores}

The Administrative services dimension of the HiEduQual instrument comprises questions 8-12, which assess students' perceptions of the administrative services such as efficiency of work, timeliness, attitude of staff, maintenance of records and accessibility. When looking at each of the four factors making up the administrative services dimension of student customer satisfaction, the expectations of the students exceed their perceptions in all five areas.

The average gap score (P-E) for the administrative services dimension of student customer satisfaction is -1.77 . The survey results show that the perception of the students of the higher educational institutions under study regarding the administrative services dimension of service quality do not meet their expectations.

A summary of the survey results for the administrative services dimension of student customer service quality are summarized in Table 4 below. 
Table 4. Administrative Services Dimension - HiEduQual Results

\begin{tabular}{lcccc}
\hline \multicolumn{1}{c}{$\begin{array}{c}\text { AS FACTOR } \\
\text { DIMENSIONS }\end{array}$} & $\begin{array}{c}\text { EXPECTATION } \\
\text { (E) }\end{array}$ & $\begin{array}{c}\text { PERCEPTION } \\
\text { (P) }\end{array}$ & $\begin{array}{c}\text { GAP } \\
\text { SCORE } \\
\text { (P-E) }\end{array}$ & $\begin{array}{c}\text { AVERAGE } \\
\text { SERVQUAL P } \\
\text { SCORE FOR AS }\end{array}$ \\
\hline $\begin{array}{l}\text { 8.Administrative staff } \\
\text { provide error free work }\end{array}$ & 5.39 & 3.60 & -1.79 & \\
$\begin{array}{l}\text { 9.Administrative staff } \\
\text { provides service without } \\
\text { delay }\end{array}$ & 5.59 & 3.35 & -2.24 & \\
$\begin{array}{l}\text { 10.Administrative staff are } \\
\text { courteous and willing to help }\end{array}$ & 5.20 & 3.51 & -1.69 & \multirow{2}{*}{3.40} \\
$\begin{array}{l}\text { 11.Administration maintains } \\
\text { accurate and retrieval records }\end{array}$ & 5.75 & 3.31 & -2.44 & \\
$\begin{array}{l}\text { 12.Administrative staff is } \\
\text { accessible during office } \\
\text { hours }\end{array}$ & 4.98 & 3.21 & -1.77 & \\
\hline \multicolumn{7}{c}{ Average Administrative Services Gap Score } \\
\hline
\end{tabular}

\subsubsection{Analysis of Academic Facilities Scores}

The Academic Facilities dimension of the HiEduQual instrument comprises questions 13-15, which assess students' perceptions of the academic facilities (teaching aids, labs, library etc.) of the higher educational institutions under study. When looking at each of the three factors making up the academic facilities dimension of student customer satisfaction, the expectations of the students exceed their perceptions in all three areas.

The average gap score (P-E) for the academic facilities dimension of student customer satisfaction is -1.20 . The survey results show that the perception of the students of the higher educational institutions under study regarding the academic facilities dimension of service quality do not meet their expectations.

A summary of the survey results for the academic facilities dimension of student customer service quality are summarized in Table 5 below.

Table 5. Academic Facilities Dimension - HiEduQual Results

\begin{tabular}{lcccc}
\hline \multicolumn{1}{c}{$\begin{array}{c}\text { AF FACTOR } \\
\text { DIMENSIONS }\end{array}$} & $\begin{array}{c}\text { EXPECTATION } \\
\text { (E) }\end{array}$ & $\begin{array}{c}\text { PERCEPTION } \\
\text { (P) }\end{array}$ & $\begin{array}{c}\text { GAP } \\
\text { SCORE } \\
\text { (P-E) }\end{array}$ & $\begin{array}{c}\text { AVERAGE } \\
\text { SERVQUAL P } \\
\text { SCORE FOR AF }\end{array}$ \\
\hline $\begin{array}{l}\text { 13.Classrooms are equipped } \\
\text { with teaching aids }\end{array}$ & 5.16 & 3.88 & -1.29 & \\
$\begin{array}{l}\text { 14.Computer/Science } \\
\text { are well equipped } \\
\text { 15.Library has adequate } \\
\text { academic resources }\end{array}$ & 5.01 & 3.69 & -1.33 & \multirow{2}{*}{3.85} \\
\hline \multicolumn{2}{c}{ Average Academic Facilities Gap Score } & 4.00 & -0.97 & \\
\hline
\end{tabular}




\subsubsection{Analysis of Campus Infrastructure Scores}

The Campus Infrastructure dimension of the HiEduQual instrument comprises questions 16 to 18 which assess students' perceptions of the campus infrastructure (sports and recreation facilities, hostel facilities, security measures) of the higher educational institutions under study. When looking at each of the three factors making up the campus infrastructure dimension of student customer satisfaction, the expectations of the students exceed their perceptions in all three areas.

The average gap score (P-E) for the campus infrastructure dimension of student customer satisfaction is -1.82 . The survey results show that the perception of the students of the higher educational institutions under study fall below their expectations with regard to the assurance dimension of higher service quality.

A summary of the survey results for the assurance dimension of customer service quality are summarized in the Table 6 below.

Table 6. Campus Infrastructure Dimension - HiEduQual Results

\begin{tabular}{|c|c|c|c|c|}
\hline $\begin{array}{l}\text { CI FACTOR } \\
\text { DIMENSIONS }\end{array}$ & $\begin{array}{l}\text { EXPECTATION } \\
\text { (E) }\end{array}$ & $\begin{array}{l}\text { PERCEPTION } \\
\text { (P) }\end{array}$ & $\begin{array}{c}\text { GAP } \\
\text { SCORE } \\
(\text { P-E) }\end{array}$ & $\begin{array}{c}\text { AVERAGE } \\
\text { SERVQUAL P } \\
\text { SCORE FOR CI }\end{array}$ \\
\hline $\begin{array}{l}\text { 16.University has sports } \\
\text { \& recreation facilities }\end{array}$ & 5.09 & 4.06 & -1.04 & \\
\hline $\begin{array}{lr}\text { 17.University } & \text { has } \\
\text { adequate } & \text { hostel } \\
\text { facilities } & \end{array}$ & 5.65 & 3.54 & -2.10 & 3.60 \\
\hline $\begin{array}{l}\text { 18. University has safety } \\
\& \text { security measures }\end{array}$ & 5.54 & 3.21 & -2.33 & \\
\hline \multicolumn{3}{|c|}{ Average Campus Infrastructure Gap Score } & -1.82 & \\
\hline
\end{tabular}

\subsubsection{Analysis of Support Services Scores}

The Support Services dimension of the HiEduQual instrument comprises questions 19-21 which assess students' perceptions of the support services (amenities, extracurricular activities, counselling) of the higher educational institutions under study. When looking at each of the five factors making up the support services dimension of student customer satisfaction, the expectations of the students of higher educational institutions under study exceed their perceptions in all three areas.

The average gap score (P-E) for the support services dimension of student customer satisfaction is -1.79 . The survey results show that the perception of the students of the higher educational institutions under study regarding the support services dimension of service quality do not meet their expectations.

A summary of the survey results for the support services dimension of student customer 
service quality are summarized in the Table 7 below.

Table 7. Support Services Dimension - HiEduQual Results

\begin{tabular}{lcccc}
\hline \multicolumn{1}{c}{$\begin{array}{c}\text { SS FACTOR } \\
\text { DIMENSIONS }\end{array}$} & $\begin{array}{c}\text { EXPECTATION } \\
\text { (E) }\end{array}$ & $\begin{array}{c}\text { PERCEPTION } \\
\text { (P) }\end{array}$ & $\begin{array}{c}\text { GAP } \\
\text { SCORE } \\
\text { (P-E) }\end{array}$ & $\begin{array}{c}\text { AVERAGE } \\
\text { SERVQUAL P } \\
\text { SCORE FOR SS }\end{array}$ \\
\hline $\begin{array}{l}\text { 19.University has adequate } \\
\text { amenities }\end{array}$ & 5.26 & 3.32 & -1.94 & \\
$\begin{array}{l}\text { 20.University organizes } \\
\text { cultural and extracurricular } \\
\text { activities }\end{array}$ & 5.62 & 3.59 & -2.02 & \multirow{2}{*}{3.58} \\
$\begin{array}{l}\text { 21.University provides } \\
\text { counselling services }\end{array}$ & 5.23 & 3.81 & -1.42 & \\
\hline \multicolumn{2}{c}{ Average Support Services Gap Score } & -1.79 & \\
\hline
\end{tabular}

\subsubsection{Analysis of Internationalization Scores}

The Internationalization dimension of the HiEduQual instrument comprises questions 22 and 23 which assess students' perceptions of the internationalization aspects (international activities, foreign teachers) of the higher educational institutions under study. When looking at the two factors making up the internationalization dimension of student customer satisfaction, the expectations of the students of the higher educational institutions under study exceed their perceptions in both areas;

The average gap score (P-E) for the internationalization dimension of student customer satisfaction is -2.39 . The survey results show that the perception of the students of higher educational institutions under study regarding the internalization dimension of service quality do not meet their expectations.

A summary of the survey results for the internationalization dimension of student customer service quality are summarized in the table 8 below.

Table 8. Internationalization Dimension - HiEduQual Results

\begin{tabular}{lcccc}
\hline \multicolumn{1}{c}{$\begin{array}{c}\text { I FACTOR } \\
\text { DIMENSIONS }\end{array}$} & EXPECTATION I & $\begin{array}{c}\text { PERCEPTION } \\
\text { (P) }\end{array}$ & $\begin{array}{c}\text { GAP } \\
\text { SCORE } \\
\text { (P-E) }\end{array}$ & $\begin{array}{c}\text { AVERAGE } \\
\text { SERVQUAL P } \\
\text { SCORE FOR I }\end{array}$ \\
\hline $\begin{array}{l}\text { 22.University promotes } \\
\text { international activities }\end{array}$ & 4.41 & 2.17 & -2.23 & \\
$\begin{array}{l}\text { 23.University has teachers } \\
\text { from abroad }\end{array}$ & 4.60 & 2.06 & -2.54 & \multirow{2}{*}{4.17} \\
\hline \multicolumn{2}{c}{ Average Internationalization Gap Score } & -2.39 & \\
\hline
\end{tabular}




\section{Discussion}

The purposes of the present research were to explore the service quality of selected higher educational institutions in Chandigarh, Punjab and Haryana.

\subsection{Teaching}

The average HiEduQual perception value for teaching dimension is 3.48 out of a possible 7 . The expectation score exceeded the perception score (-1.76 gap score) indicating that the students of higher educational institutions under study are not satisfied with the overall teaching aspects (teaching practices, course curriculum, course content, syllabus, performance evaluation etc.)

\subsection{Administrative Services}

According to the HiEduQual, the average perception value for administrative services dimension is 3.40 out of a possible 7 . The expectation score exceeded the perception score (-1.99 gap score). The students of the higher educational institutions under study were dissatisfied with the performance of all of the aspects listed under administrative services dimension (work efficiency, timeliness, availability of staff, maintenance of records, staff behaviour).

\subsection{Academic Facilities}

The average HiEduQual perception value for responsiveness is 3.85 out of a possible 7 . The expectation score exceeded the perception score ( -1.20 gap score) indicating that the students of higher educational institutions under study are not satisfied with the overall academic facilities (teaching aids, labs, libraries etc.)

\subsection{Campus Infrastructure}

The average HiEduQual perception value for campus infrastructure is 3.60 out of a possible 7 . The expectation score exceeded the perception score (-1.82 gap score). This score indicates that the students are not satisfied with the sports and recreational facilities, hostel facilities and safety and security measures.

\subsection{Support Services}

The average HiEduQual perception value for support services dimension is 3.58 out of a possible 7 . The expectations score exceeded the perceptions score (-1.79 gap score). This score indicates that the students of higher educational institutions under study are not satisfied with the overall support services (amenities, extracurricular activities, counselling services etc.).

\subsection{Internationalization}

The average HiEduQual perception value for internationalization dimension is 4.17 out of a possible 7 . This score indicates that the students of higher educational institutions under study are not satisfied with the internalization aspects (international activities, foreign teachers etc.). 


\section{Implication of the Study}

The purpose of this study was to investigate the gaps between the expected service quality and perceived service quality of higher educational institutions under study. Knowing the perceived service quality will benefit the Management of the higher educational institutions under study, as it will enable them to identify the gaps and improvise where they are lacking. Through this study, it has been found that the HiEduQual is an excellent tool that fits the Indian context well for the assessment of service quality of higher educational institutions. Hence, periodic HiEduQual student surveys must be conducted in order to assess the service quality gaps. It has been found that the institutions are lacking in all six dimensions of service quality, most of all in the internationalization dimension. A plausible explanation could be the low salaries offered in private sector teaching jobs in India as compared to foreign countries. Secondly, even though exchange programmes exist in some institutes, the number of students participating in such programmes is very small in India. This could be improved by collaborating with foreign universities. Universities could participate in Faculty exchange programmes, student exchange programmes, projects and academic activities. The second largest negative gap score was found in the administrative services dimension. One of the prime reasons is the widening communication gap between the students and the clerical staff. Also, students experience long delays in getting their work done as majority of the institutes still rely on traditional methods of documentation and bureaucratic procedures. Work efficiency of staff could be enhanced by including English language and Computer Knowledge as criteria for selection in the clerical staff. Clerical Staff must be trained as to their job roles and responsibilities. Also, they need to be sensitized about the student requirements. Records and important documents must be computerized and made available to students over a digital platform using information systems. Online submission of documents and fees must be accepted to improve efficiency and speed. The third largest gap score was found in the campus infrastructure dimension. Most institutes do not have adequate hostel facilities. Hostels are overcrowded and have poor infrastrucuture. Innovative designs and buildings are required to address the issue of lack of space in campuses. Campuses must be equipped with sports facilities and students must be encouraged to take up any sports activity free of cost. The fourth largest negative gap score was obtained in the support services dimension. Institutes must act as support systems and offer counselling services, workshops and seminars for skill up gradation and placement services apart from the course curriculum. Also, coaching in self-development, self-direction, facing interviews and writing resumes must be imparted to final year students. The fifth largest negative gap score was found in the teaching dimension. There is lack of correlation between course curriculum and job competencies. This could be solved through regular industrial visits and provision of Industrial training programs. Also, Industry Institute Partnership Programmes and Industry Institute interactions will bridge the gap between training imparted at institutes and industrial requirements. The lowest gap score was obtained in the dimension of academic facilities. This could be overcome by the incorporation of ICT in classes. Teachers must be trained in the use of PowerPoint presentations and interactive whiteboards. Campuses must offer wireless connectivity. E-library facility must be introduced so that students can access online books and study material in any part of the campus. 


\section{Limitations \& Recommendations}

There are several limitations as well as recommendations to this study. Firstly, the sample size is small. It is therefore suggested for future research to increase the number of respondents. Secondly, the respondents of the present study include only students in the selected universities and colleges in Chandigarh, Punjab and Haryana, so the findings of the present study cannot be generalized to students of other higher educational institutions and other geographical regions. For further study, it is recommended that the higher educational institutions established in other states also be included and a comparative study be conducted. Thirdly, the measurement technique in the present study was through self-rating questionnaires. Since, there is a great tendency among students to give responses that are socially acceptable, the genuine responses may not have been captured by these questionnaires. Fourthly, this study is cross-sectional in nature; hence further research through longitudinal studies needs to be conducted to confirm the results.

\section{Conclusion}

In conclusion, the present study investigated the gaps in the service quality expected and perceived by the students of selected higher educational institutions in Chandigarh, Punjab and Haryana. The overall perceived HiEduQual score for the six dimensions of student customer satisfaction is 3.68. This indicates dissatisfaction with the service quality of higher educational institutions under study. From the quantitative analysis it is found that, gaps exist in the students' expected vs. perceived level of all six service quality dimensions namely, teaching, administrative services, academic facilities, campus infrastructure, support services and internationalization. The negative gaps that exist in the expected vs. perceived level of service quality indicate the areas where improvement efforts need to be focused. Hence, it is suggested that the management at higher educational institutions enhance their service quality in the given dimensions.

\section{References}

Annamdevula, S., \& Bellamkonda, R. S. (2014). HiEduQual: An Instrument for Measuring the Critical Factors of Students' Perceived Service Quality. Management Science \& Engineering, 8(2), 103-109.

Bahadori, M., Sadeghifar, J., Nejati, M., Hamouzadeh, P., \& Hakimzadeh, M. (2011). Assessing Quality of Educational Service by the SERVQUAL model: Viewpoints of Paramedical Students at Tehran University of Medical Science. Technics Technologies Education Management, 6(4), 1058-1065

Çerri, S. (2012). Assessing the Quality of Higher Education Services using a modified SERVQUAL scale. Annales Universitatis Apulensis Series Oeconomica, 14(2), 664-679.

Chopra, R., Chawla, M., \& Sharma, T. (2014). Service Quality in Higher Education: A Comparative Study of Management and Education Institutions. NMIMS Management Review, 24(April-May), 59-72. 
Cronin, J. J., \& Taylor, S. A. (1992). Measuring service quality: A re-examination and extension. Journal of Marketing, 56(3), 55-68. http://dx.doi.org/10.2307/1252296

De Oliveira, O. J., \& Ferreira, E. C. (2009). Adaptation and application of the SERVQUAL scale in higher education. Paper presented in the POMS $20^{\text {th }}$ Annual Conference, Orlando, Florida, USA, May 1 - 4, 2009.

Department of Technical Education, Haryana. (2015, September 10). Present Status. Retrieved September 15, 2015, from Department of Technical Education, Haryana: http://techeduhry.nic.in/present_status.pdf

Directorate of Public Instructions (Colleges), Punjab. (2006). The Department. Retrieved September 15, 2015, from Directorate of Public Instructions (Colleges), Punjab: http://www.dpipunjab.org/page.php?page_id=4

Dirkse van Schalkwyk, R., \& Steenkamp, R. J. (2014). The exploration of service quality and its measurement for private higher education institutions. South African Business Review, 18(2), 83-107.

Đonlagić, S., \& Fazlić, S. (2015). Quality assessment in higher education using the SERVQUAL model. Management, 20(1), 39-57.

Enayati, T., Modanloo, Y., Behnamfar, R., \& Rezaei, A. (2013). Measuring Service Quality of Islamic Azad University of Mazandaran using SERVQUAL Model. Iranian Journal of Management Studies, 6(1), 99-116.

Kanakana, M. G. (2014). Assessing Service Quality in Higher Education using the SERVQUAL Tool. Paper presented in the International Conference on Industrial Engineering and Operations Management, Bali, Indonesia, January 7-9, 2014.

Leisyte, L., Westerheijden, D. F., Epping, E., Faber, M., \& de Weert, E. (2013). Stakeholders and Quality Assurance in Higher Education. Paper presented in the $26^{\text {th }}$ CHER conference, Lausanne, 09/11 September, 2013.

Ministry of Human Resource Development, Government of India. (2015, August 13). University and Higher Education. Retrieved September 15, 2015, from MHRD: http://mhrd.gov.in/university-and-higher-education

Mtra. Claudia Castillo Cruz, Luis Antonio Delgadillo Gutiérrez and Mtra. Graciela Lara López. (2011). Adjusting SERVQUAL Model in a High Education Library Service. Paper presented in POM $2011-22^{\text {nd }}$ Annual Conference, Reno, Nevada, USA, April 29 - May 2, 2011.

Nitin Seth, Deshmukh, S. G., \& Prem, V. (2005). Service quality models: a review. International Journal of Quality \& Reliability Management, 22(9), 913-949. http://dx.doi.org/10.1108/02656710510625211

Parasuraman, A., Zeithaml, V. A., \& Berry, L. L. (1985). A conceptual model of service quality and its implications for future research, Journal of Marketing, 49(3), 41-50. 
http://dx.doi.org/10.2307/1251430

Rasli, A., Shekarchizadeh, A., \& Iqbal, M. J. (2012). Perception of Service Quality in Higher Education: Perspective of Iranian Students in Malaysian Universities. International Journal of Economics and Management, 6(2), 201-220.

Sahney, S., Banwet, D. K., \& Karunes, S. (2015). A SERVQUAL and QFD approach to total quality education: A student perspective. International Journal of Productivity and Performance Management, 53(2), 143-166. http://dx.doi.org/10.1108/17410400410515043

Society for Promotion of IT in Chandigarh. About Us. Retrieved September 15, 2015, from Department of Higher Education, Chandigarh Administration: http://www.dhechd.org/WebSite/AboutUs.aspx

Yousapronpaiboon, K. (2013). SERVQUAL: Measuring higher education service quality in Thailand. Paper presented in the $5^{\text {th }}$ World Conference on Educational Sciences - WCES 2013. Procedia - Social and Behavioural Sciences 116, 1088-1095. http://dx.doi.org/10.1016/j.sbspro.2014.01.350

\section{Copyright Disclaimer}

Copyright reserved by the authors.

This article is an open-access article distributed under the terms and conditions of the Creative Commons Attribution license (http://creativecommons.org/licenses/by/3.0/). 